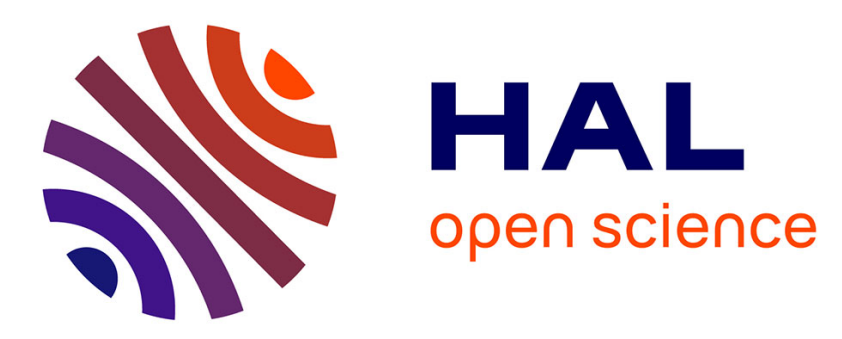

\title{
Iterative design and evaluation of rule-based cropping systems: methodology and case studies. A review
} Philippe Debaeke, Nicolas Munier-Jolain, Michel Bertrand, Laurence Guichard, Jean Marie Nolot, Vincent Faloya, Patrick Saulas

\section{- To cite this version:}

Philippe Debaeke, Nicolas Munier-Jolain, Michel Bertrand, Laurence Guichard, Jean Marie Nolot, et al.. Iterative design and evaluation of rule-based cropping systems: methodology and case studies. A review. Agronomy for Sustainable Development, 2009, 29 (1), pp.73-86. 10.1051/agro:2008050 . hal-01186780

\author{
HAL Id: hal-01186780 \\ https://hal.science/hal-01186780
}

Submitted on 31 May 2020

HAL is a multi-disciplinary open access archive for the deposit and dissemination of scientific research documents, whether they are published or not. The documents may come from teaching and research institutions in France or abroad, or from public or private research centers.
L'archive ouverte pluridisciplinaire HAL, est destinée au dépôt et à la diffusion de documents scientifiques de niveau recherche, publiés ou non, émanant des établissements d'enseignement et de recherche français ou étrangers, des laboratoires publics ou privés.

$$
\text { Copyright }
$$




\title{
Iterative design and evaluation of rule-based cropping systems: methodology and case studies. A review
}

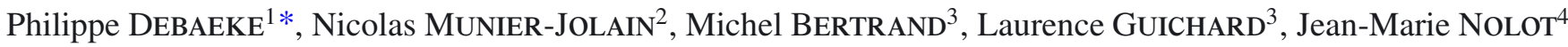 \\ Vincent FALOYA ${ }^{5}$, Patrick SAULAS ${ }^{3}$ \\ ${ }^{1}$ INRA, UMR 1248 INRA / ENSAT, Agrosystèmes et Développement Territorial, BP 52627, 31326 Castanet-Tolosan, France \\ ${ }^{2}$ INRA, UMR 1210 INRA / ENESAD / Université de Bourgogne, Biologie et Gestion des Adventices, 17 rue de Sully, BP 86510, 21065 Dijon, France \\ ${ }^{3}$ INRA, UMR 211 INRA / AgroParisTech, Agronomie, BP 1, 78850 Thiverval-Grignon, France \\ ${ }^{4}$ INRA, Domaine Expérimental d'Auzeville, BP 52627, 31326 Castanet-Tolosan, France \\ ${ }^{5}$ INRA, Domaine Expérimental d'Époisses, BP 86510, 21065 Dijon, France
}

(Accepted 6 August 2008)

\begin{abstract}
The economic and regulatory context of crop production changes rapidly, but concerns about agricultural sustainability, including environmental impacts, are increasing steadily. To cope with complexity and uncertainty, innovative methodologies are required for designing, managing and evaluating prototype cropping systems. A generic approach combining iteratively design of cropping systems and evaluation of their performances is presented in this review article. It includes 5 main steps: (1) defining the set of goals and constraints for each cropping system, (2) identifying a suitable agronomic strategy, (3) formulating the consistent set of technical decision rules, (4) applying and evaluating the rule-based system, and (5) validating or refining the strategy and the rules. This methodology was applied to a range of environmental and production contexts, in a perspective of integrated crop production (ICP) prototyping. Three cropping system experiments conducted in France were brought together to demonstrate the potentialities of this system approach and discuss the methodological bottlenecks to address. The three case studies differed by the context of crop production and resource use: adaptation to limited irrigation water (Toulouse), introduction of innovative cropping systems (Versailles), and substitution of herbicides by non-chemical methods (Dijon). The consequences of the specific objectives in each case study on the experimental design and the evaluation process were discussed. Special attention was paid to the time step of the evaluation process, the duration of the improvement loops when prototyping cropping systems, the global evaluation of the systems and the evaluation of individual decision rules.
\end{abstract}

integrated cropping systems / long-term experiment / decision rules / agronomic evaluation

\section{INTRODUCTION}

The huge diversity of soil, climatic, agronomic, economic and social contexts in an uncertain world requires a wide range of cropping systems characterised by local adaptation and flexibility in technical decision-making (Meynard and Girardin, 1991; Boiffin et al., 2001). For this reason, standard technical packages, ready to use in practice, are no longer appropriate in the current agricultural context.

To develop sustainable cropping systems, several objectives have to be considered, apart from yield or gross margin. For instance, new evaluation criteria define the technological and sanitary quality of harvested crops and require adherence to environmental norms, e.g. air and water pollutants, energy use, and the simplification of crop management sys-

* Corresponding author: philippe.Debaeke@toulouse.inra.fr tems, e.g. reduction of labour input, staggering of field operations. Sustainable cropping systems should accept strong environmental constraints such as limited water resource management, reduced reliance on pesticides, decreasing emissions of greenhouse gases, and conservation of biodiversity. Consequently, under low-input management, limiting factors and sub-optimal yields are expected, in contrast to intensive production systems. To mitigate yield decreases and compensate for the reduction in pesticide use, biological control should be promoted (Altieri, 1995; Posner et al., 1995; Meynard et al., 2003). Positive interactions between cultural practices are sought and the potential benefits of crop rotation are promoted as much as possible. Sustaining a balance in biological, physical and chemical fertility is identified as a strategy for medium- to long-term management. Based on these principles, the concept of Integrated Crop Production (ICP) was 
proposed as a reasonable trade-off between profitability and environmental protection (El Titi, 1992; Frangenberg, 2000). For instance, according to Integrated Pest Management (IPM) principles, several technical options are suggested to control disease inocula or the weed seed bank in soil, although none of them is as effective as the best chemical programme. Only a combination of techniques, each giving partial control, could replace chemical protection, and such a combination might involve major changes in the nature of the cropping system (Mortensen et al., 2000). Other environmental objectives, such as the reduction of energy costs and erosion risks, and the improvement of soil biodiversity and carbon storage might induce major changes in the whole cropping management system (sowing dates, cultivars, crop protection). Mulch-based cropping systems with direct seeding into a cover crop have been suggested as an innovation likely to solve some problems associated with crop production (Scopel et al., 2005). However, the consistency of the whole cropping system and the interactions between the techniques should be carefully considered at the beginning of the innovation process. The prototyping and evaluation of innovative cropping systems require specific methodologies accounting for this complexity.

Empiricism, on-farm surveys and field experimentation have long been the main methods used by agronomists to develop and evaluate cropping systems (Drinkwater, 2002). The literature abounds in long-term trials comparing the effects of crop rotations, mineral or organic fertilisation regimes and soil tillage programmes on yield, economic return, and biotic and abiotic components of soil fertility (e.g. Varvel, 1994; Johnston, 1997; Soane and Ball, 1998; Richter et al., 2007). These trials are generally of factorial design, with predetermined sequences of crop operations. They suffer from a major defect: systems differing by only one technique (for instance, soil tillage) are compared without checking the consistency of the whole crop management system. For example, in experiments comparing the effects of different soil tillage methods, sowing date seldom differs among them, although the optimal sowing date should probably be different for direct sowing and deep ploughing, for trafficability reasons (Buhler, 1992).

From the late ' 80 s, environmental concerns began to grow and experiments were set up to evaluate production systems less dependent upon fertilisers and pesticides, either at field or farm level. In European networks (Holland et al., 1994; Jordan et al., 1997; Vereijken, 1997; Korsath and Eltun, 2000), but also in the USA (Poudel et al., 2002; Reganold et al., 2001), the conventional approaches were compared with innovative systems, either called 'organic', 'ecological', 'integrated' or 'low-input'. Cropping systems were compared for their ability to reach predefined objectives (production level, gross margin, input level, environmental impacts) whilst meeting labour and input level constraints (e.g. Capillon and Fleury, 1986; Debaeke and Hilaire, 1997).

Studies on the farmer's decision processes clearly indicated that his reasoning could be represented by the concept of decision (or action) rules (Sebillotte and Soler, 1988; Chatelin et al., 1993; Leroy et al., 1997; Aubry et al., 1998). Usually a rule is made up of (i) a function which links the decision to the targets or the constraints, (ii) a solution which displays the possible actions as a function of the context in conditional form ("If... then...; else"), and (iii) an evaluation criterion to check whether the objectives were reached or not (Reau et al., 1996). Decision rules are applied on the basis of soil or plant indicators which are clearly formalised and accessible to the decision-maker (such as water and nitrogen balances, and visual records of diseases and weeds from crop inspections).

The consequence is that the cropping system is not simply defined by a logical and consistent sequence of crops and technical operations but results from the application of decision rules (including crop choice) depending on environmental factors and working organisation constraints (Papy, 2001).

From an experimental point of view, the cropping system research moved from the comparison of "crop management sequences", where some technical operations were fixed (because their effect on production was studied) and the others were decided by the trial manager, to the evaluation of "crop management systems" where the decision rules were formulated explicitly and became the main objects of evaluation (Reau et al., 1996). Using the concept of decision rules, the agronomist can thus account for the flexibility of cultural decisions and crop choices as a function of agronomic and economic indicators. Technical operations ( $\mathrm{N}$ fertilisation, irrigation and crop protection) are decided with reference to plant and soil status. This is a major change in the methodology of cropping system experimentation either for management, evaluation or extension.

The experimental approach at field level (from several hundreds of $\mathrm{m}^{2}$ to several hectares) could be extended by a micro-farm evaluation where different management methods are compared in parallel on a practical scale, simplifying both the evaluation of the feasibility and the dissemination of innovation (Vereijken, 1986, 1992; Viaux et al., 1994).

Meynard et al. (1996) considered several testing levels for the evaluation of cropping systems: (1) a global multi-criteria comprehensive evaluation level, to test if the management system fits generally with the assigned objectives (economic, environmental), on the basis of data collected at harvest or during the cropping season; (2) an evaluation of agronomic strategies, which consists of testing the validity of the assumptions which were formulated to design the cropping system; and (3) an analytical evaluation of single decision rules which may result in very detailed studies. In practice, these 3 levels of evaluation are combined in a cropping system experiment, and their relative weight depends on the specific objectives of the study. An important feature, however, is that data collected for decisionmaking should be clearly distinct from those used for evaluation; otherwise the decision-making process, based on extra information usually not available for farmers, would be biased. The ideal solution would be that the people in charge of decision-making would be different from those doing the evaluation.

The aim of this paper is to highlight and discuss how a common methodology for prototyping and testing cropping systems in field experiments (Nolot and Debaeke, 2003; Debaeke et al., 2006; Lançon et al., 2007) was applied to different sets of objectives and constraints, in relation to different research 
priorities in the context of integrated and sustainable crop production. The report is based on three cropping system experiments carried out by INRA in France during the last 10 years. The case studies were chosen because they share some methodological aspects while illustrating (i) the range of management options for conducting the experiment and (ii) the range of potential outputs.

The main shared features of the three experiments are presented first, before developing the objectives and a brief description of the experimental design for each site. Then the specificities of each experiment are discussed, considering among others the time step of the evaluation process, the duration of the improvement loops in the iterative design of cropping system prototypes, the global evaluation of the systems and the evaluation of individual decision rules. Detailed results cannot be given in this summary paper; therefore the reader is invited to consult the following references: Nolot and Debaeke (2003), and Debaeke et al. $(2005,2006)$ for the Toulouse experiment, Bertrand et al. (2005a, b) for the Versailles experiment, and Munier-Jolain et al. (2004) for the Dijon experiment.

\section{A COMMON APPROACH OF THE RULE-BASED CROPPING SYSTEM EXPERIMENTS}

The three experiments were designed according to the 5 main steps described by Nolot and Debaeke (2003), combining iteratively design and evaluation phases, namely: (1) defining the set of goals and constraints for each cropping system, (2) identifying a suitable agronomic strategy, (3) formulating a consistent set of decision rules in accordance with the strategy, (4) applying and evaluating the rule-based system, and (5) validating or refining the strategy and the rules.

The experimental designs were composed of large plots allowing rational use of farm machinery. The plot size (from 0.5 to $2 \mathrm{ha}$ ) is justified by the dispersal of pests and the limitation of neighbourhood effects between adjacent cropping systems. The large size of the experimental unit limits the number of replications possible. It is our opinion that, unlike in factorial trials, the objective is not to demonstrate statistically the effects of single factors nor to compare the relative performances of the different systems, but to evaluate how often the expected result is obtained. Hence, the purpose of replications differs between factorial and system experiments. In a system experiment, a sufficient number of plots is required to estimate the probability of obtaining the expected result whatever the system. However, the size of plots is not guided by work organisation concerns (labour peaks, or conflicts between operations when soil and weather conditions dictate priorities for field operations) because a typical field experiment is not suited to answering such questions. The consequences of applying innovative systems on a field scale to farm organisation should be explored by other means, such as models (Vocanson, 2006).

In the 3 case studies, the main objective of the system experiments was not to deliver one or several cropping systems directly applicable by farmers. The experiment demonstrated the feasibility of systems resulting from the application of decision rules, derived from the agronomic knowledge at a given time. Its purpose was not to look for the best cropping system: as the tested systems were defined according to different sets of objectives and constraints, their performances could not be compared on the basis of any common objective. Instead, the purpose was to test how frequently the relative or absolute objective assigned to the cropping system was reached. The evaluation criteria were the gross margin, the grain quality, the energy balance, the amount of resources used (water, other inputs), the labour use and the environmental impact on air, soil and water.

All three experiments addressed the issue of the environmental impacts of crop production, and especially the public's desire to reduce pesticide use (Aubertot et al., 2005). The reduction of the reliance on pesticides is a question arising in most European countries, where environmental concerns are increasing steadily; water quality is to be maintained or improved according to the 2000 Water Framework Directive, which aims at achieving a 'good' water quality for all water across the European Union by 2015. However, the relative contribution of the sustainability components in the evaluation of cropping systems was different between the case studies, while addressing the trade-off between contradictory objectives was a common concern.

\section{APPLICATION TO THREE CASE STUDIES: OBJECTIVES, TREATMENTS AND LAYOUTS OF THE CORRESPONDING 'CROPPING SYSTEM' EXPERIMENTS}

\subsection{The Toulouse experiment (1995-2002)}

A range of 3 agronomic contexts (A, B and C) were defined as a function of both the amount of water available for irrigation and the labour available for field work (Nolot and Debaeke, 2003; Debaeke et al., 2005, 2006). In system A, defined as productive yet environmentally-friendly, labour and water resources were not limited: up to $240 \mathrm{~mm}$ water was applied to summer crops (maize, soybean). Such a system is adopted in the valleys and terraces in south-western France by farms with 80 ha per full-time worker, where cereal and oil-protein crops are the major sources of income and where the environment (water quality) is a major concern. In system $B$, water and labour were both limited: a maximal rate of $120 \mathrm{~mm}$ was allocated to summer crops and there was one full-time worker per 160 ha, with crops as the main source of income, as in system A. The challenge was to optimise the ratio between the use of limited resources and the level of crop production. System $\mathrm{C}$ had no irrigation, and labour availability was restricted, corresponding to a farm with one part-time worker looking for a system easy to manage and robust.

For each level of water and labour availability, a range of species and cultivars was available and a yield goal was fixed, which formed a rational basis for calculating input rates. In system A, the highest possible yield and/or high crop quality were expected. The most productive crops and cultivars under full irrigation were used - generally late-maturing varieties. Water, nitrogen and plant protection requirements were 
satisfied at the highest level but not at an insurance level (for environmental and economic reasons). The crops grown were maize, soybean, spring pea and durum wheat. In system B, crops requiring low inputs were selected in order to reduce labour use, water consumption and crop management costs. For that reason, tolerance to diseases and low water and nitrogen requirements were the basis of choices, resulting in the growing of sorghum (instead of maize), sunflower (instead of soybean), winter pea (instead of spring pea) and durum wheat (as a winter crop). Reduced vegetative growth was expected from limited plant densities, reduced nitrogen fertilisation and reduced pre-anthesis irrigation in order to restrict leaf area index and prevent excessive water demand and disease development. Temporary $\mathrm{N}$ deficiencies were tolerated because reaching the maximum possible yield was not the goal. In system C, crop rationing was combined with escape strategies, by choosing a crop rotation reducing the risks of weeds, pests and diseases. The same crops as in B were chosen, with moderate water and $\mathrm{N}$ requirements or tolerant of unsatisfied demand (sorghum-sunflower-pea or faba bean-durum or soft wheat), but $\mathrm{N}$ amounts and crop densities were reduced, decreasing the risk of diseases. At the same time, the soil fertility was preserved over the medium to long term (as phosphorus, organic matter, soil structure and weed seed banks).

The experiment was located at the INRA-Auzeville experimental farm near Toulouse $\left(43.62^{\circ} \mathrm{N}, 1.45^{\circ} \mathrm{E}\right)$ and started in 1995. The experiment had 24 plots covering an area of 33 ha: 12 plots in a fixed rotation $(\mathrm{R})$ with all the crops of the rotation being present every year and 12 plots in a flexible system $(\mathrm{F})$, where the crop choice depended on agronomic considerations, such as soil structure, residual mineral nitrogen and weed infestation, together with economic considerations (i.e. the target gross margin). During the 8 years of the experiment, durum wheat was grown each year on the 3 flexible systems, while soybean was predominant in the A and B systems, and sunflower in C. The rotation ( 2 summer crops followed by two winter crops) was fixed as regards the management of weeds, nitrogen and soil-borne diseases.

\subsection{The Versailles experiment (1999-)}

The general objective of this experiment was to suggest and evaluate profitable cropping systems in accordance with technical and environmental concerns in the context of cereal cropping in the Parisian Basin. Four cropping systems were tested in this experiment, that included deeply innovative techniques and strategies:

- "High Production": This system was close to the current regional practice. The crop rotation was unchanged since the beginning of the trial in autumn 1998: oilseed rape-winter wheat-spring pea-winter wheat. The yield should only be restricted by soil and climate local conditions without any other limiting factors. The most effective inputs were used in order to reach the potential yield. Preventive sprayings were used against pests (insurance strategy). Crop cultivars were chosen according to their yield productivity and stability in the region, and, for wheat, according to high bread-making characteris- tics. The soil structure was preserved in order to maximise root development, and water and nutrient uptake. The fields were mouldboard-ploughed each year except after pea. After pea they were ploughed only occasionally when the soil structure was damaged.

- "Low Input": The crop rotation was the same, but the objective was to minimise environmental damage by reducing the chemical and mineral inputs while retaining a gross margin similar to the "High Production" system. The yield losses were compensated for by saving inputs because of reduced pest attacks with lower nitrogen and plant density. Reduced yield goals were fixed, and the pest management operations were decided when a damage threshold was reached. The pesticides were chosen according to both their environmental impacts and their efficacy/cost ratios. The varieties were chosen for their disease resistance, and wheat for its bread-making characteristics. Ploughing was done every two years before oilseed rape and pea, both to restore the soil structure and to prevent weed and disease attacks.

- "Direct seeding mulch-based": Crop management differed from the previous system only by the absence of soil tillage. To protect the soil surface, a permanent cover was maintained with commercial crops and/or cover crops (in association with the main crop or as catch crops). The crop rotation was maize-wheat-pea-wheat. The commercial crop was directseeded under the cover crop (living mulch) after a chemical desiccation or a partial restriction of the cover by either cutting or the application of a herbicide at low dose.

- "Organic": This system was applied following organic farming specifications: no mineral fertiliser, no synthetic chemicals. Wheat was grown every two years. Crop protection against pathogens was based on the use of resistant varieties and on escape strategies (delayed sowing date). Weed control was based on mechanical weeding (harrowing or hoeing). Legumes were used as green manures to enhance the soil nitrogen resource, and top-dressed organic fertilisers (guano, feather meal) were applied sparingly because of their prohibitive cost.

The experiment ( $8 \mathrm{ha})$ was located in Versailles $\left(48.81^{\circ} \mathrm{N}\right.$, $\left.2.14^{\circ} \mathrm{E}\right)$, on a deep loamy well-drained soil (17\% clay in surface, $30 \%$ in depth), prone to soil crusting but highly productive. The experimental design was composed of 2 blocks, divided into 4 plots corresponding to the 4 cropping systems. Each plot was divided into 2 sub-plots corresponding to shifted sequences of the rotation, in order to have a wheat crop present each year in each system. Sub-plots were 0.5 ha in area, which gave the opportunity to include several sub-trials (e.g. alternative variety, control strip with no fungicide, control strip with no nitrogen).

\subsection{The Dijon experiment (2000-)}

The main goal of the cropping system experiment in Dijon was to evaluate the performance of prototypes of cropping systems based on the principles of Integrated Weed Management (IWM). The experimental design was composed of 5 cropping systems (CS): a reference system, close to the 
local practices, and 4 systems, differing in their objectives and constraints, but all of them incorporating IWM principles (Munier-Jolain et al., 2004). These principles are based on diversified crop rotation, suitable soil tillage tools, false seedbed preparation, sowing dates chosen to escape weed emergence periods, weed-suppressing cultivars, mechanical weeding, and herbicide decisions optimising the trade-off between efficacy and environmental impact.

CS1 - Local standard: the objective was to maximise the economic profitability. Weed control relied mainly on chemicals. The crop rotation (oilseed rape/winter wheat/winter barley) resulted primarily from economic considerations.

CS2 - IWM, Minimum tillage. This cropping system mimicked large farms with a small workforce, and therefore excluded time-consuming operations, such as ploughing and mechanical weeding. The crop rotation was diversified by introducing a spring crop (spring barley) and a summer crop (soybean) with oilseed rape and several winter cereals within a 6-year rotation.

CS3 - IWM, No mechanical weeding: all the principles of IWM (including the diversified rotation as in CS2) were applied except mechanical weeding, which was considered timeconsuming and inappropriate on some farms.

CS4 - IWM, with mechanical weeding: in this system, all the principles of IWM were used, including mechanical weeding, and chemical control was restricted to situations where the combination of prophylactic methods and mechanical weeding did not succeed in controlling weeds. In crops grown in wide rows such as sugar beet, which was introduced as a summer crop in the rotation, herbicides were sprayed only on the rows, while hoeing was used in between rows.

CS5 - Zero herbicide: only non-chemical weed control methods were accepted in this system.

The environmental impacts of herbicides were expected to decrease from CS1 to CS5. Most of the decision rules were driven by weed management but should not increase the development of animal pests and diseases. Economic thresholds were used to trigger pesticide applications against animal pests and diseases.

The experiment was set up at the INRA-Epoisses experimental farm near Dijon (eastern central France, $47.33^{\circ} \mathrm{N}$, $\left.5.03^{\circ} \mathrm{E}\right)$ on a productive and drained clay soil (35-45\% clay). The experiment was composed of two blocks of five 2 ha fields about $1 \mathrm{~km}$ apart. Consequently, the five systems were replicated twice. The decision rules were the same in the two blocks, but did not always result in the same management, as weed flora may vary between the blocks as a result of cropping history. Crop rotations were not fixed at the beginning of the experiment but resulted from a combination of rotational principles to prevent the seed-set of some specific weeds, the ability of some crops to be mechanically weeded, and the weed composition of the field.

The main characteristics of the 3 cropping system experiments are summarised and compared in Table I. The 3 experiments took account of a range of concerns regarding regional potentialities but all aimed at reducing the use of inputs in a context of integrated crop production (ICP).

\section{SPECIFIC METHODOLOGICAL CHOICES IN EACH EXPERIMENT}

\subsection{Toulouse experiment}

The Toulouse experiment was the oldest of the three presented here. The methodology itself was a great concern for the scientific team supervising the experiment and was one of the addressed issues. The main focus was the flexibility of the cropping systems according to the agricultural context, defined by the economic objectives, the regulatory context and the availability of water and labour. The tested systems were not regarded as particularly innovative, as they were defined according to sets of objectives and constraints really existing for farmers in the Toulouse region. A practical case study (adaptation to irrigation availability), covering a large part of the agricultural context of south-western France, was chosen to initiate a generic approach associating methods to design, manage and evaluate cropping systems. However, the nature of the 4-year rotations, which were not practised by the farmers, was a response to the need for diversification in Integrated Crop Production.

The evaluation was mainly focused on the potential to optimise the cropping systems using a set of scientific knowledgeand expertise-based decision rules; so much attention was given to the formulation and evaluation of the decision rules and to developing new decision support tools (models and indicators) in order to put the rules into action. Although it was practically impossible to predict all the possible events which might affect decisions, the tested systems were consistent because most of the technical operations were based on rules.

Every rule was composed of an objective (its justification), a solution and an evaluation criterion (Tab. II). Some rules were simple ones, written according to the following syntax: "if plant or soil status is greater, equal to or lesser than [threshold], then [action 1: sow, fertilise, spray, irrigate...], else [action 2: wait, withdraw...]". However, some decisions about water and nitrogen supply were too complex to be summed up by such a rule. In such cases a decision support system specifically designed for the experiment was necessary to produce a good decision. Irrigation scheduling in systems $\mathrm{A}$ and $\mathrm{B}$ resulted from the application of a multi-species water balance model (Bil-H) (Nolot and Debaeke, 2003). On each irrigated plot, a water balance (Precipitation + Irrigation $+/-\Delta$ Soil Water Storage - Drainage - Evaporation - Transpiration) was run on a weekly step. The model estimated a satisfaction rate for crop water requirement $(\mathrm{Ta} / \mathrm{To}$ : ratio between actual and potential transpiration, which was a function of soil volume colonised by roots and of easily transferable water). The rule was summarised by a curve of Ta/To plotted against thermal time, which fixed the threshold below which irrigation should be triggered. When irrigation was triggered, the amount of water needed depended on the soil water content. The curve changed according to both the crop species and the level of crop rationing which was desired. Weather forecasts were used to bring forward irrigation in the case of wind or to defer it if rain was expected. Bil-H gave a dynamic estimate of $\mathrm{Ta} / \mathrm{To}$ over the growing season which was useful for 
Table I. Main characteristics of the 3 cropping system experimental.

\begin{tabular}{|c|c|c|c|}
\hline & Toulouse & Versailles & Dijon \\
\hline \multicolumn{4}{|l|}{ Objectives } \\
\hline Agronomic & $\begin{array}{l}\text { Adaptation to variable } \\
\text { irrigation availabilities }\end{array}$ & $\begin{array}{l}\text { Feasibility and sustainability } \\
\text { of innovative systems }\end{array}$ & $\begin{array}{l}\text { Long-term weed control in } \\
\text { IWM systems }\end{array}$ \\
\hline Environmental & $\begin{array}{l}\text { Optimising water use, } \\
\text { minimising } \mathrm{N} \text { leaching }\end{array}$ & $\begin{array}{l}\text { Minimising } \mathrm{N} \text { leaching, } \\
\text { minimising the use of } \\
\text { pesticides }\end{array}$ & $\begin{array}{l}\text { Minimising the use of } \\
\text { herbicides }\end{array}$ \\
\hline $\begin{array}{l}\text { Economic } \\
\text { (GM: Gross Margin) }\end{array}$ & $\begin{array}{l}\text { Maximising GM, minimising } \\
\text { labour time }\end{array}$ & GM equal to conventional & $\begin{array}{l}\text { No GM objective assigned } \\
\text { to systems: the experiment } \\
\text { makes it possible to } \\
\text { evaluate the cost of IWM }\end{array}$ \\
\hline \multicolumn{4}{|l|}{ Constraints } \\
\hline General & Summer and winter crops & Wheat every 2 years & \\
\hline Specific to a system & Irrigation availability & $\begin{array}{l}\text { Direct seeding in mulches } \\
\text { Organic } \\
\text { Low input }\end{array}$ & $\begin{array}{l}\text { Minimum tillage, } \\
\text { with or without mechanical } \\
\text { weeding, with or without } \\
\text { herbicide. }\end{array}$ \\
\hline Agronomic strategy & $\begin{array}{l}\text { Diversified rotation, } \\
\text { crop canopy rationing, } \\
\text { stress escape }\end{array}$ & $\begin{array}{l}\text { Spray or pests and diseases } \\
\text { escape }\end{array}$ & $\begin{array}{l}\text { Diversified rotation, soil } \\
\text { tillage, false seedbed and } \\
\text { competitive crop canopy }\end{array}$ \\
\hline Rule building & $\begin{array}{l}\text { Simulation + regional } \\
\text { expertise + local references } \\
\text { (factorial trial) }\end{array}$ & $\begin{array}{l}\text { Expert knowledge } \\
\text { Experimental references }\end{array}$ & $\begin{array}{l}\text { Simulation }+ \text { expertise }+ \\
\text { experimental references }+ \\
\text { decision support system }\end{array}$ \\
\hline $\begin{array}{l}\text { Degree of rule } \\
\text { explanation }\end{array}$ & $\begin{array}{l}+++ \text { for nitrogen, water, } \\
\text { cultivar choice } \\
+ \text { other decisions }\end{array}$ & Complete & $\begin{array}{l}+++ \text { for weed management } \\
+ \text { other decisions }\end{array}$ \\
\hline Lay-out & $\begin{array}{l}\text { Plot size }=1.5 \text { ha } \\
4 \text { replicates } \\
\text { each crop, each year } \\
1 \text { fixed rotation trial }(12 \text { plots }) \\
+1 \text { flexible trial }(12 \mathrm{p})\end{array}$ & $\begin{array}{l}\text { Plot size }=0.5 \text { ha } \\
2 \text { replicates } \\
\text { wheat each year } \\
\text { Other crops: every } 2 \text { years }\end{array}$ & $\begin{array}{l}\text { Plot size }=2 \text { ha } \\
2 \text { replicates } \\
1 \text { crop per year }\end{array}$ \\
\hline \multicolumn{4}{|l|}{ Evaluation } \\
\hline Global & $\begin{array}{l}\text { Agronomical, environmental } \\
\text { (water use, nitrate, pesticide } \\
\text { use), gross margin, labour }\end{array}$ & $\begin{array}{l}\text { Agronomical, environmental } \\
\text { (nitrate, pesticides, energy, } \\
\text { earthworms), gross margin, } \\
\text { labour }\end{array}$ & $\begin{array}{l}\text { Weed control, physical soil } \\
\text { fertility, environmental } \\
\text { (herbicides, other pesti- } \\
\text { cides, energy, GGE*, } \\
\text { nitrate), gross margin }\end{array}$ \\
\hline $\begin{array}{l}\text { Intermediate states } \\
\text { of the systems }\end{array}$ & $\begin{array}{l}\text { Disease reduction, weeds, } \\
\text { water saving }\end{array}$ & Numerous & Canopy competitiveness \\
\hline Rules & $\begin{array}{l}\text { Agronomic diagnosis }+ \\
\text { factorial trials: varieties, } \\
\text { fungicides, plant density }\end{array}$ & $\begin{array}{l}\text { Agronomic diagnosis }+ \\
\text { check plots }\end{array}$ & Check plots \\
\hline $\begin{array}{l}\text { Major revisions of } \\
\text { systems and rules } \\
\text { during the } \\
\text { prototyping }\end{array}$ & $\begin{array}{l}\text { Revision of thresholds (N } \\
\text { fertilisation, irrigation) } \\
\text { Crop changes in low-input } \\
\text { system (less durum wheat, } \\
\text { less faba bean) }\end{array}$ & $\begin{array}{l}\text { Crop changes in the organic } \\
\text { system (less oilseed rape, } \\
\text { more alfalfa) }\end{array}$ & $\begin{array}{l}\text { Increasing the proportion of } \\
\text { legumes in the rotation }\end{array}$ \\
\hline
\end{tabular}

* GGE: Greenhouse Gas Emission.

characterising water stress in rainfed crops and discussing the differences between actual and recommended irrigation schedules. As Bil-H was connected to Bil-N, a model to decide on optimal $\mathrm{N}$ fertilisation, a dynamic estimate of $\mathrm{N}$ leached was provided for the assessment of environmental impacts (Nolot and Debaeke, 2001).

During the course of the field experiment, the sets of rules piloting the 3 cropping systems were continuously improved.
Most modifications were minor, because most of the knowledge supporting the rules had been available since the beginning of the experiment. Some rules were based on results of simulations using the EPIC-Phase crop model: the choice of varieties was based on crop phenology prediction for a range of cultivars. Debaeke et al. (2006) showed that early cultivars of sorghum should be grown under rainfed management, while late-maturing ones were recommended to be irrigated. Other 
Table II. Examples of simple decision rules.

\begin{tabular}{|c|c|c|c|}
\hline $\begin{array}{l}\text { Topic } \\
\text { (experiment location) }\end{array}$ & Rule objective & Rule formulation & Evaluation criteria \\
\hline $\begin{array}{l}\text { Weed management } \\
\text { (Dijon) }\end{array}$ & $\begin{array}{l}\text { Reduction of potential } \\
\text { weed emergence in } \\
\text { autumn for winter } \\
\text { cereals through: } \\
\text { + escaping the periods } \\
\text { of weed emergence } \\
+ \text { false seedbed }\end{array}$ & $\begin{array}{l}\text { If 'autumn-emerging weeds } \\
\text { were observed during the } \\
\text { previous years } \\
\ldots \text { then shallow tillage }(5 \mathrm{~cm}) \\
\text { end of Sept.-early Oct., } \\
\text { and from } 25 \text { Oct., shallow } \\
\text { tillage with a goose-foot tine } \\
\text { cultivator }(5 \mathrm{~cm}) \text { and cereal } \\
\text { sowing as soon as possible }\end{array}$ & $\begin{array}{l}\text { - working depth of each tool } \\
\text { - for autumn-emerging } \\
\text { weeds, density on } 24 \text { Oct. > } \\
\text { density "end of winter" } \\
\text { - weed growth stage in early } \\
\text { winter < cereal stage } \\
\text { (no plants emerging before } \\
25 \text { Oct. should survive } \\
\text { after cereal sowing) }\end{array}$ \\
\hline $\begin{array}{l}\text { Sowing density } \\
\text { (Toulouse) }\end{array}$ & $\begin{array}{l}\text { Choosing sowing } \\
\text { density according to } \\
\text { yield goal, varietal } \\
\text { earliness, sowing date } \\
\text { and seedbed structure }\end{array}$ & $\begin{array}{l}\text { Varying sowing density } \\
\text { around a standard for each } \\
\text { crop (system A): } \\
\pm 10 \% \text { per } 100 \text { GDD before } \\
\text { or after the optimal sowing } \\
+ \text { correction factors for yield } \\
\text { goal, cultivar earliness and } \\
\text { expected seed loss }\end{array}$ & $\begin{array}{l}\text { - counting plant emergence } \\
\text { - factorial trial with } 3 \text { den- } \\
\text { sity } \\
\text { levels } \\
\text { - diagnosis of the factors } \\
\text { responsible for non-optimal } \\
\text { plant density }\end{array}$ \\
\hline $\begin{array}{l}\text { Disease management } \\
\text { in wheat } \\
\text { (Versailles) }\end{array}$ & $\begin{array}{l}\text { Reduction of the risk of } \\
\text { foliar disease in wheat } \\
\text { crop }\end{array}$ & $\begin{array}{l}\text { Low density rate and late } \\
\text { sowing ( } 15 \text { Oct.) } \\
\text { Mixture of } 4 \text { wheat cultivars } \\
\text { with complementary } \\
\text { susceptibility profiles to } \\
\text { foliar diseases }\end{array}$ & $\begin{array}{l}\text { - comparing sprayed and } \\
\text { unsprayed sub-plots } \\
\text { - disease assessment on } \\
\text { the } 3 \text { last expanded leaves } \\
300 \text { GDD after anthesis }\end{array}$ \\
\hline
\end{tabular}

GDD = Growing Degree-Days.

rules were based on the application of common budget models, calibrated by real-time observations on the crop canopy (for $\mathrm{N}$ fertilisation, irrigation), or were based on regional data updated each year (variety choice, crop protection thresholds). However, these data are only available for conventional systems, and therefore they might have to be adapted for innovative low-input cropping systems and integrated pest management. 'Grey' knowledge and individual or collective expertise were needed to design some decision rules such as, for example, the adaptation of sowing density as a function of sowing date and water availability (Tab. II), or the adaptation of crop rotations to enhance natural regulation of pests and diseases and reduce the need for pesticides. However, analytical tests within the experimental design made it possible to check the validity of these decision rules by comparing variants on small plots.

Minor changes in the decision thresholds were introduced if enough evidence was found for these modifications. However, sometimes, the whole rule had to be drastically altered or the decision thresholds had to be changed to cope with changes in the socio-economic or technical context, or simply because the intermediate objectives had not been reached. We identified two situations where the initial rule (rule structure or thresholds) had to be modified: (i) a given rule could be updated due to the technical (for instance, new cultivars with innovative traits) or economic context (for instance, crop prices, input costs); however, the annual evaluation of a given rule could lead to growing the same cultivar or crop species for 2-3 years for agronomic evaluation; (ii) some components of the cropping system were changed when they obviously did not suit the chosen objectives. For example, substituting durum wheat by bread wheat in low-input systems was required because of poor grain quality. Only the introduction of a new durum wheat cultivar with a high protein concentration despite a low $\mathrm{N}$ fertility level could have resulted in a return of durum wheat to the low-input system.

Some decision thresholds were index-linked to the price environment. The relationship between the threshold value and the economic context defined a meta-rule, i.e. a rule for adjusting the parameters of a function used for decision-making. The irrigation thresholds changed with the crop type but also with the crop price, for a given water cost (Fig. 1). If the crop price was high, irrigation was triggered for higher levels of soil water content. Enough knowledge was available to build operational relationships between decisions and the economic context.

These decision tools were the main outputs of the experiment, along with evidence demonstrating their ability to optimise management at the cropping system level in contrasting situations. However, the data collected also clearly demonstrated that a significant reduction in inputs (when correctly decided) may not reduce the net income in the economic context of the late '90s (Nolot and Debaeke, 2003), while improving indicators of environmental impact. The evaluation of the economic return of the three cropping systems accounted for the year to year variability of yields and input levels due 


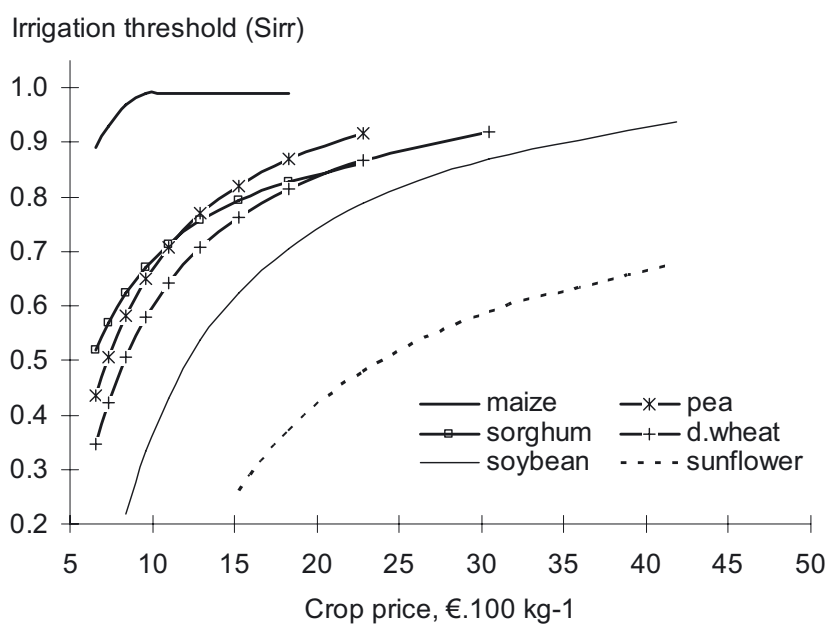

Figure 1. - An example of rule improvement - type (i): evolution of the irrigation-triggering threshold ( $\operatorname{Sirr}=\mathrm{Ta} / \mathrm{To}$ ) as a function of crop prices for 6 major crops in Toulouse; water cost was fixed at $1.35 € . \mathrm{mm}^{-1}$.

to the variability in the weather. As the considered variables (water balance, air-borne leaf diseases, crop yields) were only slightly affected by long-term processes (except long-term soil $\mathrm{N}$ availability as affected by the cropping system), the 8-year duration of the experiment was mainly justified by the analysis of the effects of weather on the rule sensitivity and on the likelihood of reaching the production targets.

As the evaluation was usually done annually, increasing the number of years for system testing improved the evaluation by allowing a risk assessment to be included. The experimental design also included all the phases of the rotation each year, which helped in interpreting the inter-annual variability (Cady, 1991). This was possible only because the number of systems and the rotation length were limited: 12 plots were necessary for this objective ( 3 systems $\times 1$ rotation $\times 4$ terms). The replication applied to the set of decision rules which generated the cropping systems, but not to the annual choices which were produced by the application of the rules. The rules resulted in a range of different sequences of technique implementation, because of differences in the soil status and the weather.

In this experiment, considerable effort was put into agronomic diagnosis, which progressively added to the knowledge supporting the decision rules. The within-field heterogeneity was used for this purpose by considering several areas for crop and soil monitoring within a field of 1-2 ha. Each field included different areas dedicated to different evaluation levels: (i) evaluation on the field scale (1.5 ha), where the experiment manager applied the decision rules and evaluated the results with simple methods (Were the decision rules feasible? Did the final results reach the expected targets?); (ii) evaluation using data collected from 6-9 agronomic georeferenced stations $\left(100 \mathrm{~m}^{2}\right)$ for agronomic diagnosis (time-course of leaf area index, above-ground biomass, $\mathrm{N}$ uptake, yield components, weed population and disease damage); and (iii) evaluation using results from an analytical area (1/3 of the field area, up to 500 plots of $10 \mathrm{~m}^{2}$ ) where alternative management options (variety, plant population, crop protection, and their major interactions) were tested. This experimental layout was possible only because of the large size of the fields and because variety trials were included within the fields; in return, these variety trials benefited from the diversity of cropping systems and the environmental characterisation.

\subsection{Versailles experiment}

Unlike the Toulouse experiment, the cropping systems tested in the Versailles experiment were not chosen according to constraints currently encountered by actual farms. The purpose was to design new cropping systems to cope with likely future constraints to crop production, such as reducing the release of pesticides into the environment and improving the energy balance of cropping systems. The extension of organic farming in areas with cereal-based cropping systems was also considered. Innovative techniques in the region of the Parisian Basin, such as direct crop seeding under a permanent living mulch in a zero-tillage system, were introduced in the cropping system experiment. As initial knowledge was lacking at the beginning of the experiment for some of the systems to be tested, namely mulch-based, Integrated and Organic without any cattle manure, the sets of decision rules were continuously improved during the experiment. In this approach, the experiment is part of the cropping system prototype design, that included several improvement loops that were used to modify the rule-sets towards a system satisfying the requirements and the objectives (Fig. 2). This iterative approach was similar to problem-solving methods used in industrial production chains for quality control and continuous improvement, such as the well-known Plan-Do-Check-Act (PDCA) cycle (Meynard and Savini, 2003), a four-step model which is repeated for introducing changes into practices (Fig. 2). Using this learning process for setting up new cropping systems, the set of agronomic strategies and of decision rules (including thresholds for decision triggering, and crop and cultivar choices) may be revised during the course of the experiment, while the objectives and constraints assigned to cropping systems should remain fixed throughout.

Over the years the cropping system gradually changed from a prototype to a realistic system, and finally, to a system in accordance with the set of objectives. The periods of building up and evaluation alternated with time. As the cropping systems were very innovative, with unpredictable impacts on the environment and a real difficulty in suggesting suitable and robust decision rules, the time step of the improvement loop was short (typically one or a few years). As these cropping systems were not fully controlled, frequent modifications of the decision rules were necessary before getting a consistent set of rules addressing the objectives. Compromises were discovered progressively as the experts had only a partial vision of each system. For example, growing oilseed rape in the organic cropping system was rapidly abandoned because pollen beetle attacks were not adequately controlled. After 5 years of experimentation, the crop sequence in the organic cropping system had to be changed with the introduction of alfalfa to control thistles. The nature of permanent cover in the 


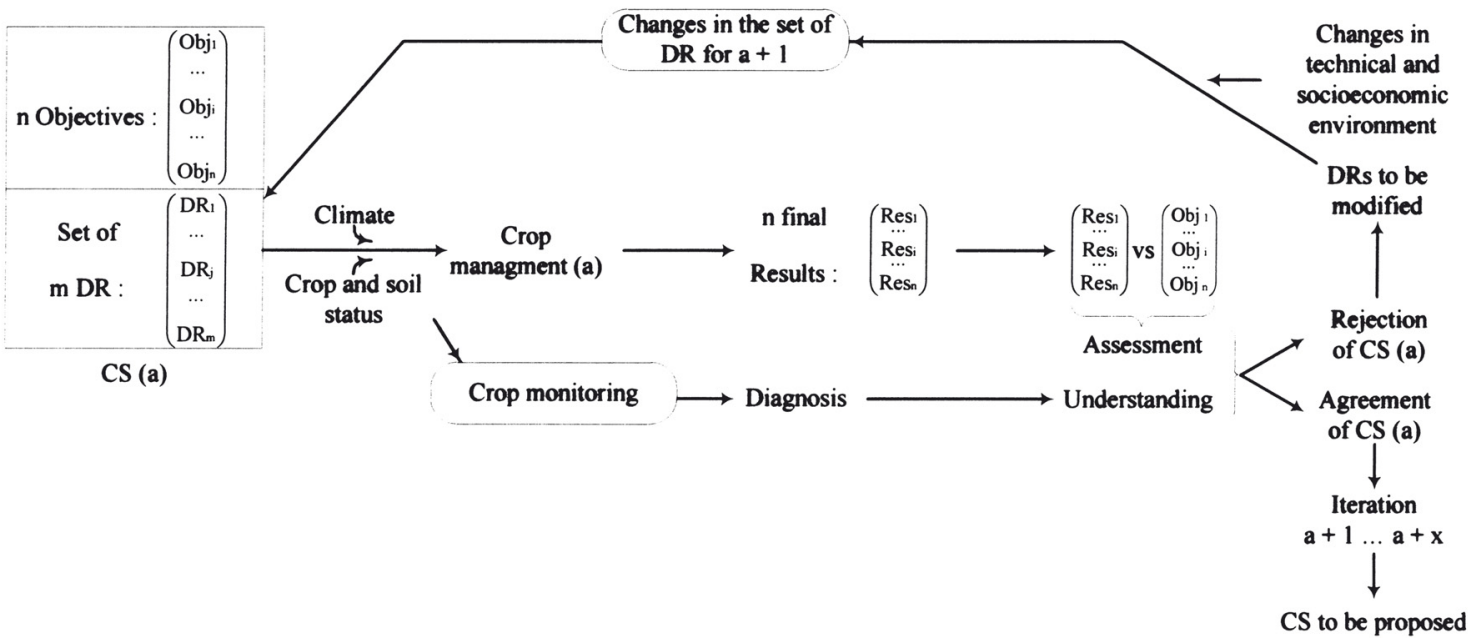

Figure 2. The approach used for setting up cropping systems: the annual improvement loop. CS: cropping system; DR: decision rule; a: annual index.

mulch-based cropping system was changed several times (red fescue, white clover and then alfalfa) to limit the adverse effect of mulch on succeeding crops. The techniques to control the early growth of the living mulch were also modified. Glyphosate (non-selective herbicide) rates were adapted to the objective, either to depress or suppress the permanent cover.

Each individual improvement loop could be short (from 1 year to 5 years to define the crop rotation in the organic system), but the sequence of successive improvement loops for different sets of techniques required a long-term experiment for designing/evaluating innovative cropping systems (permanent soil cover, stockless organic systems requiring a 2-yr conversion period). This approach required specific attention to the evaluation of individual decision rules, with experimental designs including checking plots for rule evaluation. For example, different wheat cultivars including mixtures of up to 4 cultivars were tested in the Integrated Production cropping system in parallel strips. The data obtained over several years demonstrated that the combination of cultivar resistances to a range of diseases within a mixture reduced the risk of damage due to leaf diseases, and improved the mean yield level in cropping systems with reduced reliance on fungicides.

The long experimental duration is also required because the innovative cropping systems were likely to modify some soil properties, with cumulative effects during the course of the experiment. In the mulch-based cropping system, the organic matter content in the soil surface layers was modified and had probably still not reached its new equilibrium after 8 years. The absence of soil tillage and the changes in the organic matter status of the soil probably interacted to affect the soil structure, and thus indirectly the crop behaviour and the associated decision rules. In the organic cropping system, $\mathrm{N}$ availability for crops relies on $\mathrm{N}$ mineralisation, and therefore on the soil $\mathrm{N}$ content, that is likely to be affected after cessation of the fertilisation regime at the beginning of the experiment.

The main output of the Versailles experiment was to deliver different relevant and validated sets of decision rules corresponding to innovative cropping systems to suit the requirements expected for future cropping systems. Unlike the Toulouse experiment, the focus was not at this early stage to develop decision support systems or simple models for supporting crop management, but to demonstrate the technical feasibility of those systems. However, as soon as the prototype systems became stable and robust, the data collected also provided significant information about the technical, economic and environmental performances of the proposed cropping systems. The difficulty was to separate the prototyping function (which assumes a progressive tuning of the prototype) from the sustainability evaluation function, which requires a stable, unchanging system under test. In fact, some errors in the management, due to an insufficient evaluation of some risks or an inadequate understanding of innovative technology, could also have a significant influence on the system's success. The assessment of the risks associated with a wrong application of the set of decision rules is also an output of the experiment.

In addition, the experimental site offered conditions for interdisciplinary studies: each year an area was sown with wheat cv. Charger (a cultivar susceptible to fusarium) to study the conditions for mycotoxin production and accumulation in wheat grains. The amount and quality of organic matter in the soil was also analysed because the systems differed in their organic matter accumulation and tillage practices. These analytical studies, carried out by scientific teams not involved in the supervision of the cropping system experiment, benefited from the special conditions offered by the tested systems, and were possible in spite of the limitations related to the experimental layout.

\subsection{Dijon experiment}

In the Dijon experiment, the main research focus was the cumulative effects of combining different techniques for weed 
management, each of which having only limited potential efficiency. The tested cropping systems were undoubtedly new in French conditions and were proposed to address the major environmental concern of the concentration of herbicides in both the surface and ground-waters (Aubertot et al., 2005). However, the innovation introduced arose mainly from new combinations of common cultural practices: in IWM systems, ancestral techniques such as mouldboard ploughing were combined with mechanical control based on rotary hoes, finger weeders or flex-tine harrows, which have been used for decades in organic agriculture. The experiment provided new data to judge the performance of these cropping systems, which fitted in between organic farming and conventional systems relying mainly on chemicals for weed control.

Unlike the Versailles experiment, the set of decision rules for each system had to be fixed on the basis of expected results before starting the field evaluation, and remained unchanged (or only slightly changed) over a period long enough to assess the cumulative effects of the cropping system components on the weed community. Indeed, the long-term control of weeds is a major aspect of the assessment of sustainability: one system using very few herbicides and generating high financial return would not be judged sustainable if the weed infestation were to increase over the considered period. The set of decision rules had to be kept stable in order to relate the sustainability indicators to well-identified systems. Hence, the time step of the iterative loop was long. The role of the experiment was mainly to evaluate the system as a whole.

A set of IWM principles was fully described before field testing. The different criteria to assess the performance of cropping systems were as follows: (i) weed control - did the decision rules succeed in controlling weeds at a stable level with no severe damage to crop production? (ii) ecological was the floristic biodiversity promoted? (iii) agronomic - did the decision rules for weed control provoke unexpected agronomic side-effects, such as disease increase? (iv) environmental - did the systems result in a significant reduction in herbicide applications and related environmental impacts, did they improve energy balances, did they result in decreases in greenhouse gas emission and $N$ leaching? and (v) socio-economic - did the IWM systems result in an increase in labour use, did the input reduction compensate for the yield losses and extra input costs? These criteria covered most of the range of sustainability indicators.

As for the other two experiments, the methodology was based on formal decision rules. The knowledge available for writing formal rules came from very diverse sources. Model simulations supported the structure and parameterisation of some decision rules. For instance, the rule defining the sowing date for winter cereals (sowing after 25 October) was justified by simulation studies performed with the germinationemergence module of AlomySys (Colbach et al., 2005), a demography model for blackgrass (Alopecurus myosuroïdes Huds.), a typical weed species in winter cereals. These simulations suggested that delaying sowing until the end of October would result in a reduction of $75 \%$ in blackgrass emergence in wheat as compared with a normal sowing date in the region (i.e. at the beginning of October). The escape strategy (me- chanical control of early blackgrass seedlings shortly before sowing) was responsible for this positive effect. Other rules were based on expert knowledge when simulation models failed to help decision-making. For example, weed demography models at the community level still do not make predictions of the effect of crop rotation on weeds. Thus, the principles for defining a typical 6-year rotation were derived from available knowledge about the timing of emergence and the seed persistence in the soil for the most frequent weeds. These principles suggested (i) spreading out the sowing dates over the crop rotation as far as possible, but also (ii) limiting the frequency of spring-sown crops, because the seed persistence of spring-emerging species in the soil seed bank tends to be longer than that of the autumn-winter-emerging species (Barralis et al., 1988). Finally, as in the other two experiments, some rules were based on results from within-field testing of different options. Such a subsidiary experiment supported, for example, the choice of wheat cultivars competitive with weeds, as little information was available on this feature in the description of local varieties.

As in the Toulouse experiment, a specific tool for supporting the decision-making was developed for one complex decision, i.e. decision-making for chemical weed control (to spray or not to spray? using which herbicide?), that could not be formulated by an "if... then" statement. Theoretical studies showed that the concept of an economic damage threshold is not applicable to weed flora management (Munier-Jolain et al., 2002). In addition, the analysis of farmers' decision-making for weed control, based on farm surveys, demonstrated the multi-criteria nature of this decision (Macé et al., 2007). The decision results from a weighting of different criteria, including the efficacy of the weed control method according to the weed composition, the cost of the strategy, and its suitability for the farmer's labour plan. For managing a cropping system experiment on weeds, the formalisation of decision rules required the development of a specific decision support system based on multicriteria choice (Munier-Jolain et al., 2005). An environmental impact criterion was included in the decisionmaking process to account for the sustainability of the tested cropping systems. The complex decision was governed by the recommendations of the software as soon as this was reliable enough. Testing the recommendations led to the improvement of the decision support system, especially its ergonomics and ability to support decisions in real time.

Unlike the Toulouse experiment, the experimental design in Dijon did not include the principle of growing each year all the crops of the rotation, because IWM required long crop rotations. Moreover, the rotation was not fixed but flexible, as it could be modified on a given field according to the weed composition (e.g. as a function of the relative contribution of autumn- and spring-emerging species). The analysis of yield variability was not a main issue considered anyway. The two replicates of a given system had shifted rotation sequences in order to result in two different climatic sequences for each system.

The main output of the Dijon experiment is a global and multicriteria assessment of innovative cropping systems over an appropriate time period in a particular climate. The reliance 

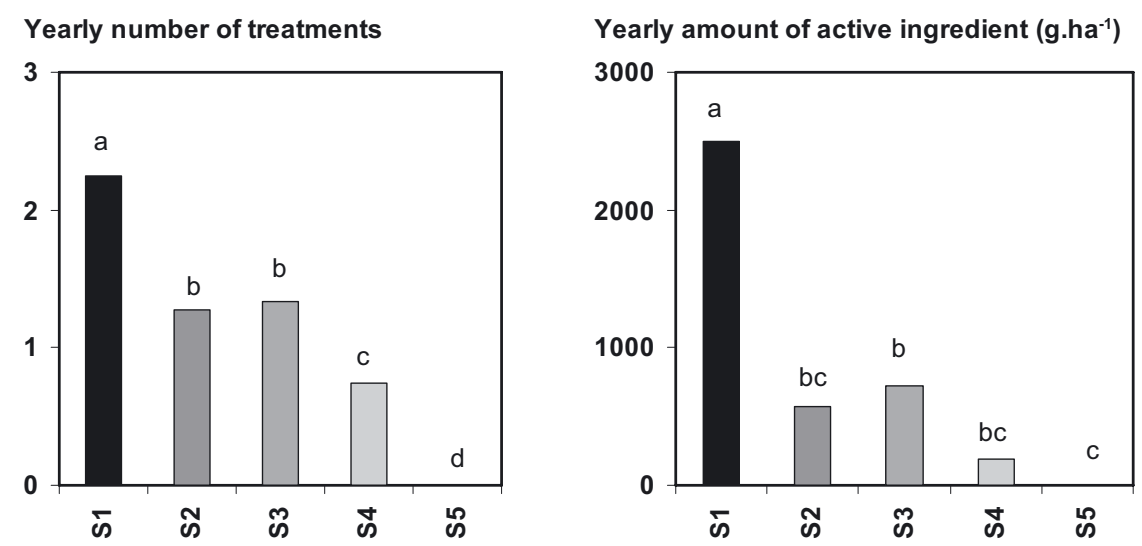

Figure 3. Two criteria for assessing the reliance of cropping systems on herbicides: comparison of (A) the mean yearly number of herbicide treatments and (B) the mean yearly amount of herbicide active ingredients applied on cropping systems in the Dijon experiment. S1: standard system; S2: IWM, reduced tillage; S3: IWM, no mechanical weeding; S4: IWM with mechanical weeding; S5: no herbicide. Average values were computed over the 2001-2006 period, except that the year with a sugar beet crop grown only in S4 was excluded from the analysis to avoid the bias due to this particular crop. Bars with the same letters are not significantly different according to LSD $(P<0.05)$.

on herbicides over six years was reduced in IWM cropping systems as compared with the standard one: the number of treatments was reduced by $65 \%$ and the amount of applied active ingredients by $90 \%$ in a typical IWM cropping system (Fig. 3), while the weed infestation remained stable or decreased over the 2001-2006 period. Other potential environmental impacts are currently being evaluated to check that the high frequency of shallow tillage in IWM cropping systems (false seedbed and mechanical weeding) does not worsen the energy balance. The feasibility and economic performance of the most promising system on the whole area of a given farm is also evaluated by modelling labour organisation. The data collected on the experiment improved our knowledge of the effects of cropping systems on weed communities. The results are also expected to provide significant inputs to the controversial debate about the future of agriculture in the European Union, addressing the important issue of the trade-off between the two components of sustainability, namely, the economics and the environmental concerns. From this point of view, although it shares part of the methodological approach with the Toulouse and the Versailles experiments, the Dijon experiment's philosophy remains closer to previous cropping system experiments comparing conventional, integrated and/or organic cropping systems (e.g., Reganold et al., 2001; Poudel et al., 2002).

\section{COMMON METHODOLOGICAL BOTTLENECKS AND WAYS OF IMPROVEMENT}

Considering soil fertility change, experiments over less than 10 years are qualified as short-term, and long-term records (several decades) are recommended for $\mathrm{C}$ cycling evaluation (Richter et al., 2007). Poor management can hamper the academic and practical value of such long-term experiments. Rule-based cropping system experiments are shorter (8-12 years), but because of repeated and heavy observations, strong and stable scientific and human resources are also com- mitted. Beyond their financial and human costs, some methodological difficulties should be pointed out.

The first limitation is due to the restricted soil and climatic representativeness of these experiments, although a tested system may have a regional relevance in terms of the types of crops and type of resource management, for instance. A large part of south-western France is affected by limited water availability, which justified the Toulouse experiment. In Versailles, winter wheat was grown every two years as a component of cereal crop systems in the Parisian Basin, while no local animal waste was available for the organic system because local farms no longer rear cattle. Most of the conversions to organic agriculture were observed in stockless farms during the last decade in this region. However, the experimental results come from a few fields in only one location. The large size of the unit plots in a cropping system experiment (from 0.5 to $2 \mathrm{ha}$ ) limits the opportunities for ample replication. Unlike normal factorial trials, the objective is not to demonstrate statistically the effects of single factors or to compare the relative performance of the different systems, but to evaluate how often the expected result was reached (and why, if not). Hence, the purpose of replication differs between factorial and system experiments. In a system experiment, a sufficient number of plots is required to estimate the probability of obtaining the expected result whatever the system. For instance, in Dijon, 8 fields managed under IWM were monitored, and this made it possible to evaluate the weed control in IWM over 8 fields. However, as each system was replicated only twice in this experiment, one could argue that the satisfactory results obtained might be due to chance, and this could hinder the dissemination of the results for wider use.

Two approaches might be used to expand the results obtained from local cropping system experiments. On the one hand, modelling the effects of cropping systems on a range of variables considered in the evaluation process might make it possible to explore wide ranges of climatic scenarios on different soil types (Wallach et al., 2006). Field results obtained from a limited number of data sets would be more robust if 
they were confirmed by biotechnical models based on the processes involved in the complex behaviour of the system. On the other hand, farm networks managed by extension services for testing promising sets of decision rules are another way of broadening the assessment of their validity domain. This is in line with 'step 5' of the methodology proposed by Vereijken (1997) for prototyping farming systems. During this step, the prototype variants tested on pilot farms are disseminated to a growing number of farms with a gradual shift in supervision from scientists to extension workers. In France, the results obtained from those experiments on experimental farms that demonstrated the efficiency of systems with few chemical inputs are currently playing an important role as precursors for field testing of cropping systems based on IPM principles on farm fields supervised by a network of extension workers (ICS, the Innovating Cropping System project funded by the French Ministry of Agriculture) (Reau and Landé, 2006; Debaeke et al., 2008).

The second limitation of the cropping system field experiment is related to the field scale, which might limit a realistic evaluation of systems for some aspects. On the field scale, the evaluation cannot take into account the spatial dimension, which should be considered for some issues. For example, crop attacks by mobile pests depend on the landscape structure and the distribution of cropping systems on spatial scales far larger than the field. The ecological balance of animal pests and auxiliaries might also be affected by the landscape structure and the management of crops and other components of the landscape. In the same way, the farm organisation constraints (competition for equipment, labour, water and other resources) cannot be considered directly from data collected on the field scale. However, as previously, modelling could help in evaluating the consequences for labour organisation on the farm scale of modifying the crop rotation (and therefore the crop distribution over the farm), and of delaying or anticipating the application of technical operations (Attonaty et al., 1993; Chatelin et al., 1993).

In the previous experiments, the agronomists intended to introduce innovations able to satisfy rising environmental concerns. Which innovation is to be introduced into the cropping system and to what extent it is acceptable or reasonable are two complex questions to address. As an example, the cropping systems in Dijon did not include forage crops because of the absence of livestock farming in the region. This choice was questionable as it is agreed that sowing temporary grasslands is a good way of reducing weed seed banks from annual crops, thus reducing the use of herbicides. Introducing forage crops in a stockless region would have required finding profitable outlets for them. For that reason, such a solution, although agronomically efficient, was not considered as relevant in the Dijon experiment. Searching for the innovation(s) likely to fit best with the objectives and constraints ascribed to a cropping system is also questionable. Where should the innovation come from? From the scientist's creative brain? From cropping systems already implemented in other parts of the world? From the current practices of individual farmers searching for new solutions by themselves? In Versailles, the idea of testing direct seeding in living mulch under temperate conditions was imported from previous successful experiences in tropical regions and from organic farming experiences. In Brazil, for instance, the adoption of a direct seeding mulch-based cropping system (DMC) was introduced 30 years ago to increase carbon levels in the topsoil and reduce erosion (e.g. Bernoux et al., 2006). In organic farming, temporary living mulches in which the main crop is directly sown could suppress weeds efficiently with minimum competition to the main crop.

The methodology to build and evaluate cropping systems in experimental stations on a field scale could be profitably used in on-farm programmes where innovative systems are proposed and tested with the help of volunteer farmers on pilot farms. In the Netherlands, cropping systems previously validated on experimental farms were tested in a pilot farm network (Langeveld et al., 2005). In France, such a network is currently being established by a group including scientists, extension workers and farmers wishing to innovate in their crop management systems (Reau and Landé, 2006). The prototyping approach does not plan to transfer the sets of decision rules from the experimental farms to the network directly. The method scheduled should rather begin with a discussion of the sets of decision rules with each farmer to account for the specific objectives and constraints of the farms in the network. Candidate systems will be proposed by collective expertise and discussed, they will be evaluated using forecast agroecological and economic indicators, and the most promising will be tested on-farm. The method follows previous attempts for prototyping crop management systems in tropical and temperate agriculture (see, for example, Lançon et al., 2007).

\section{CONCLUSION}

The cropping system experiments presented in this article differ from previous long-term experiments because they supported studies of the complexity of the crop production system: first of all because the consistency of the systems was accounted for by considering (i) the consistency between the techniques used within a system, and (ii) the consistency between the techniques and the environmental conditions, through the formalisation of the system management by sets of decision rules; secondly, because the assessment of the performances of the cropping systems involved various criteria covering most of the indicators of crop production sustainability. They shared a common methodology requiring first that the context, objectives and constraints of each tested system be defined, followed by the strategies and sets of decision rules, before field implementation. However, beyond this shared methodology, the three experiments had their own specific features and research focuses. Roughly, the Toulouse experiment focused on methodological developments, ex post agronomical diagnosis and the development of decision tools to adapt the strategies to the environmental and economic context. The mean feature of the experiment in Versailles was to test very innovative strategies requiring frequent tunings of the sets of decision rules and an improvement loop with a short time step. In contrast, the Dijon experiment tested cropping systems on a criterion subjected to cumulative effects, 
therefore requiring stable sets of decision rules during a long period.

\section{REFERENCES}

Altieri M.A. (1995) Agroecology: the science of sustainable agriculture, Intermediate Technology Publications Ltd (ITP), London, UK, $433 \mathrm{p}$.

Attonaty J.M., Chatelin M.H., Poussin J.C., Soler L.G. (1993) Advice and decision support systems in agriculture: new issues. Farm level information systems, Woudschoten, Zeist, The Netherlands, pp. 89-101.

Aubertot J.N., Barbier J.M., Carpentier A., Gril J.J., Guichard L., Lucas P., Savary S., Savini I., Voltz M. (2005) Pesticides, Agriculture et Environnement. Réduire l'utilisation des pesticides et en limiter les impacts environnementaux, Synthèse de l'expertise scientifique collective INRA-CEMAGREF, $63 \mathrm{p}$.

Aubry C., Papy F., Capillon A. (1998) Modelling decision-making processes for annual crop management, Agr. Syst. 56, 45-65.

Barralis G., Chadoeuf R., Lonchamp J.P. (1988) Longévité des semences de mauvaises herbes annuelles dans un sol cultivé, Weed Res. 28, $407-418$.

Bernoux M., Cerri C.C., Cerri C.E.P., Neto M.S., Metay A., Perrin A.S., Scopel E., Razafimbelo T., Blavet D., Piccolo M.D., Pavei M., Milne E. (2006) Cropping systems, carbon sequestration and erosion in Brazil, a review, Agron. Sustain. Dev. 26, 1-8.

Bertrand M., Guichard L., de Tourdonnet S., Saulas P., Picard D. (2005a) Evaluation of the agronomic, economic and environmental impacts of no-tillage cropping systems. Results of a long-term experiment in France, Proceedings of the III World Congress on Conservation Agriculture, Nairobi, Kenya, CD-Rom.

Bertrand M., Guichard L., Meynard J.M., Picard D., Saulas P. (2005b) Conception de systèmes de culture durables et innovants en grande culture. Le cas de l'essai de longue durée de "La Cage" à Versailles, $10^{\mathrm{e}}$ Colloque International du SIFEE, Angers, CD-Rom.

Boiffin J., Malezieux E., Picard D. (2001) Cropping systems for the future, in: Nösberger J., Geiger H.H., Struik P.C. (Eds.), Crop Science, Cab International, pp. 261-279.

Buhler D.D. (1992) Population dynamics and control of annual weeds in corn (Zea mays) as influenced by tillage systems, Weed Sci. 40, 241-248.

Cady F.B. (1991) Experimental design and data management of rotation experiments, Agron. J. 83, 50-56.

Capillon A., Fleury A. (1986) Conception d'itinéraires techniques respectant la diversité des exploitations agricoles : les enseignements d'un essai, Bulletin Technique d'Information, Ministère de l'Agriculture 408, 281-294.

Chatelin M.H., Aubry C., Leroy P., Papy F., Poussin J.C. (1993) Pilotage de la production et aide à la décision stratégique, Cah. Économ. Sociol. Rurales 28, 119-138.

Colbach N., Dürr C., Roger-Estrade J., Caneill J. (2005) How to model the effects of farming practices on weed emergence, Weed Res. 45, $2-17$.

Debaeke P., Hilaire A. (1997) Production of dryland and irrigated crops under different crop rotations and input levels in Southwestern France, Can. J. Plant Sci. 77, 539-548.

Debaeke P., Nolot J.M., Raffaillac D. (2005) Mise au point de systèmes de culture adaptés à la ressource en eau : enseignements tirés de l'expérimentation SGCI de Toulouse (1995-2002), C.R. Acad. Agric. Fr. 91, 1-19.
Debaeke P., Nolot J.M., Raffaillac D. (2006) A rule-based method for the development of crop management systems applied to grain sorghum in south-western France, Agr. Syst. 90, 180-201.

Debaeke P., Petit M.S., Bertrand M., Mischler P., Munier-Jolain N., Nolot J.M., Reau R., Verjux N. (2008) Évaluation des systèmes de culture en stations et en exploitations agricoles : où en sont les méthodes? in: Reau R., Doré T. (Eds.), Des systèmes de culture innovants et durables : quelles méthodes pour les mettre au point et les évaluer? Educagri editions, pp. 149-168.

Drinkwater L.E. (2002) Cropping systems research: reconsidering agricultural experimental approaches, Hortechnology 12, 355-361.

El Titi A. (1992) Integrated farming: an ecological farming approach in European agriculture, Outlook Agr. 21, 33-39.

Frangenberg A. (2000) Sustainable development of agricultural process and consequences of the implementation of Agenda 21. Integrated crop management as fundamental basis for sustainable production, Pflanzenschutz-Nachrichten Bayer 53, 131-153.

Holland J.M., Frampton G.K., Cilgi T., Wratten S.D. (1994) Arable acronyms analysed - a review of integrated arable farming systems research in Western Europe, Ann. Appl. Biol. 125, 399-438.

Johnston A.E. (1997) The value of long-term field experiments in agricultural, ecological, and environmental research, Adv. Agron. 59, 291-333.

Jordan V.W.L., Hutcheon J.A., Donaldson G.V., Farmer D.P. (1997) Research into and development of integrated farming systems for less-intensive arable crop production: experimental progress (1989-1994) and commercial implementation, Agr. Ecosyst. Environ. 64, 141-148.

Korsaeth A., Eltun R. (2000) Nitrogen mass balances in conventional, integrated and ecological cropping systems and the relationship between balance calculations and nitrogen runoff in an 8-year field experiment in Norway, Agr. Ecosyst. Environ. 79, 199-214.

Langeveld J.W.A., van Keulen H., de Haan J.J., Kroonen-Backbier B.M.A., Oenema J. (2005) The nucleus and pilot farm research approach: experiences from The Netherlands, Agr. Syst. 84, 227-252.

Lançon J., Wery J., Rapidel B., Angokaye M., Gerardeaux E., Gaborel C., Ballo D., Fadegnon B. (2007) An improved methodology for integrated crop management systems, Agron. Sustain. Dev. 27, 101-110.

Leroy P., Deumier J.M., Debaeke P. (1997) Aide à la décision pour la gestion des systèmes irrigués en grande culture, Actes du Colloque "Aide à la décision et choix de stratégies dans les entreprises agricoles ", INRA \& Conseil Régional de Picardie, Laon, 10-11 décembre 1996, pp. 101-108.

Macé K., Morlon P., Munier-Jolain N., Quere L. (2007) Time scales as a factor in decision-making by French farmers on weed management in annual crops, Agr. Syst. 93, 115-142.

Meynard J.M., Doré T., Lucas P. (2003) Agronomic approach: cropping systems and plant diseases, C.R. Biol. 326, 37-46.

Meynard J.M., Girardin P. (1991) Produire autrement, Le Courrier de l'Environnement INRA 12, 25-31.

Meynard J.M., Reau R., Robert D., Saulas P. (1996) Évaluation expérimentale des itinéraires techniques, in: Expérimenter sur les conduites de cultures: un nouveau savoir-faire au service d'une agriculture en mutation, DERF-ACTA, Paris, pp. 63-72.

Meynard J.M., Savini I. (2003) La désintensification : point de vue d'un agronome, Dossier de l'Environnement de l'INRA 24, 23-32.

Mortensen D.A., Bastiaans L., Sattin M. (2000) The role of ecology in the development of weed management systems: an outlook, Weed Res. 40, 49-62. 
Munier-Jolain N.M., Chauvel B., Gasquez J. (2002) Long-term modelling of weed control strategies: analysis of threshold-based options for weed species with contrasted competitive abilities, Weed Res. 42,107-122.

Munier-Jolain N.M., Faloya V., Davaine J.B., Biju-Duval L., Meunier D., Martin C., Charles R. (2004) A cropping system experiment for testing the principles of integrated weed management: first results, In Annales AFPP, XII ${ }^{\mathrm{e}}$ colloque international sur la biologie des mauvaises herbes, Dijon, pp. 147-156.

Munier-Jolain N.M., Savois V., Kubiak P., Maillet-Mézeray J., Jouy L., Quere L. (2005) DECID'Herb, a decision support system on the WEB, designed for sustainable weed management in cultivated fields, Proc. XIIIth Conf. EWRS, Bari, Italy.

Nolot J.M, Debaeke P. (2001) A generic model to manage N in cropping systems differing by water availability, Proc. 11th Nitrogen Workshop, Reims, France, 9-12 September 2001, pp. 401-402.

Nolot J.M., Debaeke P. (2003) Principes et outils de conception, conduite et évaluation de systèmes de culture, Cah. Agric. 12, 387-400.

Papy F. (2001) Interdépendance des systèmes de culture dans l'exploitation, in: Malézieux E., Trébuil G., Jaeger M. (Eds.), Modélisation des agroécosystèmes et aide à la décision, CIRADINRA, pp. 51-74.

Posner J.L., Casler M.D., Baldock J.O. (1995) The Wisconsin integrated cropping systems trial: combining agroecology with production agronomy, Am. J. Alternative Agric. 10, 98-107.

Poudel D.D., Horwath W.R., Lanini W.T., Temple S.R., van Bruggen A.H.C. (2002) Comparison of soil $\mathrm{N}$ availability and leaching potential, crop yields and weeds in organic, low-input and conventional farming systems in northern California, Agr. Ecosyst. Environ. 90, 125-137.

Reau R., Meynard J.M., Robert D., Gitton C. (1996) Des essais factoriels aux essais "conduite de culture", in: Expérimenter sur les conduites de cultures: un nouveau savoir-faire au service d'une agriculture en mutation, DERF-ACTA, Paris, pp. 52-62.

Reau R., Landé N. (2006) Évaluation a priori de systèmes de cultures innovants conçus par des experts et adaptés à des contextes régionaux, Rapport final de l'action 1, Projet ADAR “ systèmes de culture innovants ", $27 \mathrm{p}$.
Reganold J.P., Glover J.D., Andrews P.K., Hinman H.R. (2001) Sustainability of three apple production systems, Nature 410, 926-930.

Richter D.D., Hofmockel M., Callaham M.A., Powlson D.S., Smith P. (2007) Long-term soil experiments: Keys to managing Earth's rapidly changing ecosystems, Soil Sci. Soc. Am. J. 71, 266-279.

Scopel E., Findeling A., Chavez Guerra E., Corbeels M. (2005) Impact of direct sowing mulch-based cropping systems on soil carbon, soil erosion and maize yield, Agron. Sustain. Dev. 25, 425-432.

Sebillotte M., Soler L.G. (1988) Le concept de modèle général et la compréhension du comportement de l'agriculteur, C.R. Acad. Agric. Fr. $74,59-70$.

Soane B.D., Ball B.C. (1998) Review of management and conduct of long-term tillage studies with special reference to a $25-\mathrm{yr}$ experiment on barley in Scotland, Soil Till. Res. 45, 17-37.

Varvel G.E. (1994) Rotation and nitrogen fertilization effects on changes in soil carbon and nitrogen, Agron. J. 86, 319-325.

Vereijken P. (1986) From conventional to integrated agriculture, Neth. J. Agr. Sci. 34, 387-393.

Vereijken P. (1992) A methodic way to more sustainable farming systems, Neth. J. Agr. Sci. 40, 209-223.

Vereijken P. (1997) A methodical way of prototyping integrated and ecological arable farming systems (I/EAFS) in interaction with pilot farms, Eur. J. Agron. 7, 235-250.

Viaux P., Lemaitre G., Gouet J.P., Robert D. (1994) Étude expérimentale de systèmes de production en grande culture, in: Recherchessystème en agriculture et développement rural : Symposium international, Montpellier, pp. 248-257.

Vocanson A. (2006) Évaluation ex ante d'innovations variétales en pois d'hiver (Pisum sativum L.) : approche par modélisation au niveau de la parcelle et de l'exploitation agricole, Thèse INA PG, 294 p.

Wallach D., Makowski D., Jones J.W. (2006) Working with dynamic crop models: evaluation, analysis, parameterization and applications, Elsevier, Amsterdam, The Netherlands, 447 p. 